\title{
UPACARA PAWIWAHAN DALAM AGAMA HINDU
}

\author{
Luh Sukma Ningsih, \\ ningsihsukma754@gmail.com, \\ I Wayan Suwendra, suwendra99@gmail.com
}

\begin{abstract}
ABSTRAK
Tujuan dari penelitian ini untuk mengetahui : pengertian, tujuan, sistem, dan rangkaian upacara pawiwahan dalam agama Hindu. Teori yang digunakan untuk mengkaji masalah pawiwahan adalah teori libido,teori gender dan teori makna. Metode pengumpulan data yang digunakan dalam penyajian ini yaitu pencatatan dokumen yang bersumber dari buku, surat-surat resmi dan situs-situs web. Metode penyajian data yang digunakan adalah deskriptif literer. Berdasarkan analisis data dapat diperoleh hasil sebagai berikut: pengertian upacara pawiwahan adalah upacara yang sakral dimana seorang laki-laki dan perempuan mengikatkan diri secara lahir bathin sebagai suami istri untuk membangun rumah tangga yang harmonis melalui suatu upacara pembersihan secara sekala dan niskala, tujuan upacara pawiwahan ada tiga yaitu dharmasampati, praja, dan rati, sistem pawiwahan dalam kitab Manava Dharmasastra disebutkan ada delapan yaitu Brahma Wiwaha, Daiwa Wiwaha, Arsa Wiwaha, Prajapati Wiwaha, Asura Wiwaha, Gandharva Wiwaha, Raksasa Wiwaha, Paisaca Wiwaha dan dalam adat bali ada empat sistem pawiwahan yaitu sistem memadik/meminang, sistem ngerorod/ngerangkat, sistem nyentana, dan sistem kejangkepan, rangkaian upacara pawiwahan adalah sebagai berikut: menentukan hari baik, ngekeb, penjemputan calon mempelai wanita, mungkah lawang, mesegeh agung, mekalakalaan, mewidhi widana, dan mejauman.
\end{abstract}

Kata Kunci : Upacara Pawiwahan, Agama Hindu.

\section{ABSTRACT}

The purposes of this research is to find out: meaning, purpose, system and series of pawiwahan ceremonies in Hinduism. Theories used to study the problem of pawiwahan are libido theory, gender theory and meaning theory. The data collection method used in this presentation is the recording of documents sourced from books, official letters and websites. The data presentation method used is descriptive literary. Based on data analysis the following results can be obtained: the meaning of a pawiwahan ceremony is a sacred ceremony in which a man and woman commit themselves physically and spiritually as husband and wife to build a harmonious household through a purification ceremony at a physically and spiritually, the purpose of the pawiwahan ceremony is three namely dharmasampati, praja, and rati, the pawiwahan system in the book of Manawa Dharmasastra there are eight mentioned namely Brahma Wiwaha, Daiwa Wiwaha, Arsa Wiwaha, Prajapati Wiwaha, Asura Wiwaha, Gandharva Wiwaha, Raksasa Wiwaha, Paisaca Wiwaha, and in Balinese customs there are four systems of pawiwahan namely the memadik /meminang system, the ngerorod / ngerangkat system, the nyentana system, and the kejangkepan system, the series of pawiwahan ceremonies are as follows: determining the good day, ngekeb, picking 
Jurnal Widya Sastra Pendidikan Agama Hindu, Vol. 3, No. 22020

e-ISSN : 2656-7466, p-ISSN : 1907-9559

up the bride, mungkah lawang, mesegeh agung, mekala-kalaan, mewidhi widana, and mejauman.

Keywords: Pawiwahan Ceremony, Hinduism.

\section{PENDAHULUAN}

Agama Hindu mengenal ajaran Panca Yadnya yang artinya lima korban suci yang tulus ikhlas. Bagian dari Panca Yadnya yaitu Dewa Yadnya, Pitra Yadnya, Rsi Yadnya, Manusia Yadnya dan Bhuta Yadnya. Dewa yadnya adalah persembahan atau korban suci dengan tulus iklas yang di tujukan kepada sang pencipta (Ida Sang Hyang Widhi Wasa) beserta dengan manifestasinya. Pitra yadnya adalah suatu bentuk persembahan atau korban suci yang di tujukan kepada roh-roh para leluhur dan bhatara-bhatara. Rsi yadnya adalah suatu bentuk persembahan yang di tujukan kepada para rsi, orang suci, pinandita, pandita, sulinggih, guru, dan orang suci yang berhubungan dengan agama Hindu. Sedangkan manusia yadnya adalah suatu upacara suci yang bertujuan untuk memelihara hidup, mencapai kesempurnaan dalam kehidupan dan kesejahteraan manusia selama hidupnya. Dan Bhuta Yadnya adalah suatu upakara/upacara suci yang ditujukan kepada bhuta kala.

Selain mengenal ajaran Panca Yadnya, agama Hindu juga mengenal ajaran Catur Asrama dan Catur Purusa Artha. Dimana Catur Asrama adalah empat tingkatan atau jenjang yang dijalani manusia untuk mencapai moksa, sedangkan Catur Purusa Artha yaitu empat kekuatan atau dasar kehidupan menuju kebahagiaan. Ajaran Catur Asrama yaitu brahmacari, grahasta, wanaprastha, dan bhiksuka atau sanyasin dan Catur Purusa Artha yakni dharma, artha, kama, dan moksa merupakan tujuan dari kehidupan ini. Pada masa brahmacari sesorang menuntut ilmu kebajikan guna memperoleh pekerjaan (dharma, dan artha), pada masa grahasta atau berumah tangga sesorang akan mencari kekayaan untuk memenuhi keinginanya (kama) yang berlandaskan kebenaran atau dengan caracara yang baik (dharma). Pada masa wanaprastha seseorang mulai sedikit demi sedikit mengurangi keinginan atau hawa nafsu (kama) dan mulai mencari ketenangan guna mencapai kelepasan (moksa). Pada masa bhiksuka atau sanyasin seseorang telah dapat mencapai kelepasan (moksa) dan tidak lagi terikat dengan hal-hal yang bersifat keduniawian.

Dalam memasuki masa Grahasta diawali dengan suatu upacara yang disebut dengan Wiwaha Samskara (upacara perkawinan). Upacara Pawiwahan termasuk dalam pelaksanaan upacara Manusia yadnya. Upacara adalah serangkaian tindakan atau perbuatan yang terikat pada aturan tertentu berdasarkan adat istiadat, agama, dan kepercayaan. Menurut Koentjaraningat (1992) menyatakan upacara adat adalah suatu bentuk acara yang dilakukan dengan bersistem dengan dihadiri secara penuh masyarakat, sehingga dinilai dapat membuat masyarakat merasa adanya kebangkitan dalam diri mereka. Pawiwahan adalah ikatan suci dan komitment seumur hidup menjadi suami-istri dan merupakan ikatan sosial yang paling kuat antara laki laki dan perempuan. Bagi masyarakat Hindu wiwaha memiliki kedudukan yang khusus didalam dunia kehidupan mereka. Berdasarkan kitab Manusmrti, Wiwaha bersifat religious dan obligator karena dikaitkan dengan kewajiban untuk melahirkan seorang "putra" untuk menebus dosa-dosa orang tua mereka. Wiwaha didalam Agama Hindu dipandang sebagai sesuatu yang amat mulia. Dalam upacara pawiwahan melibatkan tiga kesaksian yaitu: Bhuta saksi (upacara mabyakala), Dewa saksi (upacara natab banten pawiwahan, mapiuning di Sanggah pamerajan), dan 
Jurnal Widya Sastra Pendidikan Agama Hindu, Vol. 3, No. 22020

e-ISSN : 2656-7466, p-ISSN : 1907-9559

Manusa saksi (dengan hadirnya prajuru adat, dan sanak keluarga/ undangan lainnya).

Dari latar belakang diatas dapat dirumuskan masalah sebagai berikut: (1) apa pengertian upacara pawiwahan?, (2) apa saja tujuan upacara pawiwahan?, (3) apa saja sistem upacara pawiwahan?, (4) bagaimana rangkaian upacara pawiwahan dalam agama Hindu?. Dan tujuan dari penulisan artikel ini adalah: (1) untuk mengetahui pengertian upacara pawiwahan, (2) untuk mengetahui tujuan upacara pawiwahan, (3) untuk mengetahui sistem pawiwahan, (4) untuk mengetahui rangkaian upacara pawiwahan dalam agama Hindu.

Teori yang digunakan adalah teori libido, teori gender dan teori makna. Menurut pendapat Kaplan (dalam, DeLamater dan Morgan Sill, 2005), dan Wimpie Pangkahila (2001) dapat disimpulkan bahwa teori libido merupakan suatu bentuk keinginan atau dorongan yang mengarah pada hubungan seksual dan proses ini secara umum tidak disadari oleh seseorang. Kaitannya dalam penelitian ini teori libido digunakan untuk mengkaji tujuan upacara pawiwahan yaitu memiliki keturunan yang akan melanjutkan amanat dan kewajiban kepada leluhur dengan suatu proses bertemunya benih laki-laki dan benih wanita yang sudah melalui upacara penyucian (mabyakala). Menurut pendapat Bem (1981), Mosse (2007) dan Fakih (2008) dapat disimpulkan bahwa gender adalah pembedaan jenis kelamin yang mencakup penampilan, kepribadian, dan tanggung jawab antara laki-laki dan perempuan yang dibangun secara sosial dan kultural. Kaitannya dalam penelitian ini teori gender digunakan untuk mengkaji pengertian upacara pawiwahan yaitu seorang laki-laki dan perempuan mengikatkan diri secara lahir bathin sebagai suami istri untuk membangun rumah tangga dan menjalankan tanggung jawab bersama. Menurut pendapat Pateda (2001), Djajasudarma (1999), dan Ullman (1972) dapat disimpulkan bahwa teori makna adalah gabungan dari maksud dan perkataan yang diberikan kepada suatu bentuk kebahasan. Dalam penelitian ini teori makna digunakan untuk mengkaji tentang makna upacara pawiwahan serta makna disetiap rangkaian upacaranya.

\section{METODE PENELITIAN}

Metode pengumpulan data yang digunakan yaitu pencatatan dokumen yang bersumber dari buku, surat-surat resmi dan situs-situs web. Penyajian data merupakan salah satu kegiatan dalam pembuatan laporan hasil penelitian yang telah dilakukan agar dapat dipahami dan dianalisis sesuai dengan tujuan yang diinginkan. Data yang disajikan harus sederhanaan jelas agar mudah dibaca. Penyajian data juga dimaksudkan agar para pengamat dapat dengan mudah memahami apa yang kita sajikan untuk selanjutnya dilakukan penilaian atau perbandingan. Metode penyajian data yang digunakan adalah deskriptif literer. Menurut Burhan Bungin metode literatur adalah salah satu metode pengumpulan data yang digunakan dalam metodologi penelitian sosial untuk menelusuri data histories. Sedangkan Sugiyono menyatakan bahwa Literatur merupakan catatan peristiwa yang sudah berlalu yang berbentuk tulisan, gambar, atau karya-karya monumental dari seseorang. Penelitian literatur ini menggunakan metode analisis data yaitu reduksi data. Menurut Sugiyono (2009: 92) mereduksi data berarti merangkum, memilih hal-hal yang pokok, memfokuskan pada hal-hal yang penting, dicari tema dan polanya.

\section{HASIL DAN PEMBAHASAN}


Jurnal Widya Sastra Pendidikan Agama Hindu, Vol. 3, No. 22020

e-ISSN : 2656-7466, p-ISSN : 1907-9559

\section{Pengertian Upacara Pawiwahan}

Dari sudut pandang etimologi kata pawiwahan berasal dari kata dasar "wiwaha". Dalam Kamus Bahasa Indonesia disebutkan kata wiwaha berasal dari bahasa sansekerta yang artinya pesta pernikahan. Menurut Undang-Undang Perkawinan No. 1 Tahun 1974 pasal 1 disebutkan "perkawinan ialah ikatan lahir bathin antara seorang pria dengan seorang wanita sebagai suami istri dengan tujuan membentuk keluarga (rumah tangga) yang bahagia dan kekal berdasarkan KeTuhanan Yang Maha Esa". Upacara pawiwahan merupakan persaksian baik ke hadapan Ida Sang Hyang Widhi Wasa maupun pada masyarakat bahwa kedua orang tersebut mengikatkan diri sebagai suami istri, dan segala akibat perbuatannya menjadi tanggung jawab mereka bersama. Di samping itu upacara tersebut juga merupakan pembersihan terhadap sukla swanita (bibit) serta lahir bathinnya. Hal tersebut dimaksudkan agar bibit dari kedua mempelai bebas dari pengaruh-pengaruh buruk (gangguan Bhuta Kala), sehingga kalau keduanya bertemu (terjadi pembuahan) akan terbentuklah sebuah "manik" yang sudah bersih. Dengan demikian agar roh yang akan menjiwai manik tersebut adalah roh yang baik/suci dan kemudian akan lahirlah seorang anak yang berguna di masyarakat. Pawiwahan dalam Agama Hindu adalah yadnya dan perbuatan dharma. Wiwaha merupakan momentum awal dari Grahasta Asrama yaitu tahapan kehidupan berumah tangga. Tugas pokok di dalam suatu pawiwahan menurut lontar Agastya Parwa yaitu mewujudkan suatu kehidupan yang disebut Yatha Sakti Kayika Dharma yang artinya dengan kemampuan sendiri melaksanakan Dharma. Menurut pandangan Agama Hindu bahwa pawiwahan adalah yajna (kewajiban suci) karena dengan perkawinan di harapkan akan melahirkan anak yang suputra.

Dengan demikian upacara pawiwahan adalah upacara yang sakral dimana seorang laki-laki dan perempuan mengikatkan diri secara lahir bathin sebagai suami istri untuk membangun rumah tangga yang harmonis melalui suatu upacara pembersihan secara sekala dan niskala.

\section{Tujuan Pawiwahan}

Menurut I Made Titib (2006) dalam makalah "Menumbuhkembangkan pendidikan agama pada keluarga" disebutkan bahwa tujuan pawiwahan menurut agama Hindu yaitu: (1) Dharmasampati yaitu kedua mempelai secara bersamasama melaksanakan Dharma yang meliputi semua aktivitas dan kewajiban agama seperti melaksanakan Yadnya. (2) Praja yaitu kedua mempelai mampu melahirkan keturunan yang akan melanjutkan amanat dan kewajiban kepada leluhur, melalui yadnya dan lahirnya putra yang suputra seorang anak akan dapat melunasi hutang jasa kepada leluhur (Pitra rna), kepada Dewa (Dewa rna) dan kepada para guru (Rsi rna). (3) Rati yaitu kedua mempelai dapat menikmati kepuasan seksual dan kepuasan-kepuasan lainnya (artha dan kama) yang tidak bertentangan dan berlandaskan dharma.

Dalam agama Hindu, pawiwahan adalah terbentuknya sebuah keluarga yang berlangsung sekali dalam hidup manusia. Hal tersebut dinyatakan dalam kitab Manawa Dharmasastra ( Pudja dan Rai Sudharta, 1977) sebagai berikut:

"Anyoyasyawyabhicaro bhawedamaranantikah

esa dharmah samasena neyah stripumsayoh parah"

Artinya: 
Hendaknya supaya hubungan yang setia berlangsung sampai mati, singkatnya ini harus dianggap sebagai hukum tertinggi sebagai suami istri (Manawa Dharmasastra IX. 101)

"Tatha nityam yateyatam stripumsau tu kritakriyau

yatha nabhicaretam tau

wiyuktawitaretaram"

Artinya:

Hendaknya laki-laki dan perempuan yang terikat dalam ikatan perkawinan, mengusahakan dengan tidak jemu-jemunya supaya mereka tidak bercerai dan jangan hendak melanggar kesetiaan antara satu dengan yang lain" (Manawa Dharmasastra IX. 102)

Dengan demikian tujuan wiwaha adalah mendapatkan keturunan dan menebus dosa para orang tua dengan menurunkan seorang putra yang suputra sehingga akan tercipta keluarga yang bahagia di dunia (jagadhita) dan kebahagiaan kekal (moksa).

\section{Sistem Pawiwahan dalam Agama Hindu} menyebutkan :

Menurut agama Hindu dalam kitab Manawa Dharmasastra III. 21

"Brahmo daiwastathaiwarsah prajapatyaastathasurah,

gandharwo raksasaccaiwa

Artinya : paicacacca astamo'dhamah"

Macam-macam cara itu ialah Brahmana, Daiwa, Rsi (Arsa), Prajapati, Asura, Gandharwa, Raksasa dan Paisaca (Pisaca).

Dari penjelasan kitab Manawa Dharmasastra ada delapan bentuk pawiwahan yaitu: (1) Brahma wiwaha adalah bentuk perkawinan yang dilakukan dengan memberikan seorang wanita kepada seorang pria ahli weda pilihan orang tuanya. (2) Daiwa wiwaha adalah bentuk perkawinan yang dilakukan dengan memberikan seorang wanita kepada seorang pendeta. (3) Arsa wiwaha adalah bentuk perkawinan yang terjadi karena kehendak kedua belah pihak keluarga lakilaki dan perempuan dengan menyerahkan sapi atau lembu menurut kitab suci. (4) Prajapati wiwaha adalah bentuk perkawinan dengan memberikan anak perempuannya oleh orang tuanya setelah menasehati kedua mempelai untuk menjalankan perkawinan dengan baik. (5) Asura wiwaha adalah bentuk perkawinan seorang laki-laki menerima wanita setelah ia memberi harta sebanyak yang diminta oleh pihak wanita. (6) Gandharva wiwaha adalah bentuk perkawinan berdasarkan cinta sama cinta dimana pihak orang tua tidak ikut campur. (7) Raksasa wiwaha adalah bentuk perkawinan si pria mengambil paksa wanita dengan kekerasan. (8) Paisaca wiwaha adalah bentuk perkawinan seorang lakilak memperkosa gadis ketika tidur atau dengan cara memberi obat hingga mabuk.

Dari sistem perkawinan tersebut tidak sepenuhnya dapat diterima dalam kehidupan masyarakat sekarang. Sistem perkawinan yang tidak bisa diterapkan yaitu Asura Wiwaha, Raksasa Wiwaha, dan Paisaca Wiwaha karena sistem tersebut bertentangan dengan norma agama dan norma hukum.

Bentuk Pawiwahan menurut adat di Bali ada empat yaitu : (1) Sistem memadik/meminang dipandang sebagai bentuk perkawinan yang paling terhormat 
menurut adat Bali maupun menurut agama Hindu. Perkawinan dengan cara ini biasanya dilakukan apabila diantara calon mempelai laki-laki dan wanita telah memiliki hubungan satu sama lain yang kemudian disepakati untuk melangsungkan perkawinan. (2) Sistem ngerorod/ngerangkat, bentuk perkawinan ini lebih lumrah disebut dengan istilah kawin lari. Pada umumnya yang dimaksudkan dengan perkawinan lari adalah bentuk perkawinan yang tidak didasarkan atas lamaran orang tua tetapi berdasarkan kemauan kedua pihak yang bersangkutan karena tidak mendapat persetujuan dari orang tua laki-laki atau perempuan. (3) Sistem nyentana adalah bentuk perkawinan yang menyimpang dari bentuk perkawinan yang umum di Bali. Tidak seperti perkawinan lainnya baik itu dengan cara memadik maupun ngerorod yang berakibat masuknya pihak wanita kedalam keluarga pihak laki-laki, dalam perkawinan nyentana justru pihak laki-laki yang masuk ke dalam keluarga pihak wanita. Dalam perkawinan nyentana, pihak laki-laki keluar dari keluarga asalnya dan masuk ke keluarga wanita. Perkawinan ini berakibat status laki-lakinya berubah dari purusa menjadi predana. (4) Sistem kejangkepan yaitu perkawinan atas kehendak orang tua kedua belah pihak untuk menjodohkan anaknya.

\section{Rangkaian Upacara Pawiwahan Menentukan Hari Baik}

Keluarga yang akan melakukan upacara pawiwahan memilih hari baik sesuai dengan kalender Hindu Bali, hari baik dipilih mulai dari calon mempelai pria datang untuk nyedek (memberitahukan) dan hari melangsungkan pernikahan sesuai hari yang disepakati oleh kedua belah pihak keluarga. Pemilihan hari baik diyakini akan mempengaruhi kelancaran melakukan upacara tersebut dan juga kehidupan mereka sebagai suami istri saat berumah tangga nantinya.

\section{Ngekeb}

Dalam pernikahan tradisional adat Bali, proses upacara ngekeb adalah untuk mempersiapkan calon pengantin wanita, seperti melakukan luluran pada tubuh. Persiapan ini untuk menyambut datangnya calon pengantin pria. Upacara Ngekeb bertujuan untuk mempersiapkan mental calon pengantin dan berdoa kepada kepada Ida Sang Hyang Widi agar dianugrahkan kebahagiaan lahir dan batin.

\section{Penjemputan Calon Mempelai Wanita}

Mempelai wanita dijemput oleh keluarga mempelai laki-laki untuk di bawa ke rumah mempelai laki-laki. Saat penjemputan, calon mempelai wanita sudah siap dengan menggunakan pakaian tradisional adat Bali diselimuti kain kuning tipis dari ujung rambut sampai ujung kaki, kain tersebut mengandung filosofi calon mempelai sudah siap untuk meninggalkan masa lajangnya menuju ke masa berumah tangga.

\section{Mungkah Lawang}

Utusan dari calon mempelai laki-laki datang untuk mengetok pintu kamar calon pengantin wanita, di saat tersebut juga dibarengi tembang-tembang Bali yang mengisyaratkan akan kedatangan pihak laki-laki, meminta agar dibukakan pintu. Dan selanjutnya calon mempelai wanita di bawa kerumah kediaman mempelai laki-laki.

\section{Mesegeh Agung}

Sebelum memasuki pekarangan rumah, kedua mempelai melakukan proses mesegeh agung. Upacara mesegeh agung bermakna sebagai ungkapan selamat datang kepada calon pengantian wanita. Kain kuning yang menutupi tubuh mempelai wanita akan dibuka oleh calon ibu mertuanya ditukar dengan uang satakan yang bermakna sebagai menyambut dunia baru dan mengubur segala masa lalu.

\section{Mekala-kalaan atau Mabyakala}


Upacara Mabyakala yaitu upacara untuk membersihkan lahir batin terhadap kedua mempelai terutama terhadap sukla swanita, yaitu sel benih pria dan sel benih wanita agar menjadi janin yang suputra. Sebelum upacara mabyakala, dilakukan upacara puja astuti oleh pemimpin upacara. Selanjutnya membakar tetimpug sampai berbunyi sebagai simbol pemberitahuan kepada bhuta kala yang akan menerima pakala-kalaan. Kedua mempelai berdiri melangkahi tetimpug sebanyak tiga kali dan selanjutnya menghadap banten pabyakalaan. Kedua tangan mempelai dibersihkan dengan segau/tepung tawar, kemudian natab pabyakalaan. Selajutnya masing-masing ibu jari kaki dari kedua mempelai disentuh dengan telur ayam mentah di depan kakinya sebanyak tiga kali. Selanjutnya kedua mempelai dilukat dengan pengelukatan. Upacara selajutnya adalah berjalan mengelilingi banten pesaksian dan kala sepetan yang sebut dengan "murwa daksina". Saat berjalan, mempelai wanita berada didepan sambil menggendong sok dagangan (simbol menggendong anak), diiringi mempelai pria dengan memikul tegen-tegenan (simbol keras untuk memperoleh nafkah kehidupan). Setiap melewati kala sepetan, ibu jari kanan di sentuh dengan bakul lambang dari kala sepetan. Mempelai wanita saat berjalan dicemati (dipukuli) dengan tiga buah lidi oleh si pria sebagai simbol telah terjadi kesepakatan untuk sehidup semati. Yang terakhir, kedua mempelai memutuskan benang pepegatan sebagai tanda mereka berdua telah memasuki masa Grahasta. Beberapa perlengkapan dalam Pabyakalaan seperti :

(1) Sanggah Surya di sebelah kanan digantungkan biyu lalung dan disebelah kiri sanggah digantungkan sebuah kulkul berisi berem. Sanggah Surya merupakan niyasa (simbol) stana Sang Hyang Widhi Wasa. Biyu lalung adalah symbol kekuatan purusa dari Sang Hyang Widhi dan Sang Hyang Purusa ini bermanifestasi sebagai Sang Hyang Semara Jaya, sebagai dewa kebajikan, ketampanan, kebijaksanaan simbol pengantin pria. Kulkul berisi berem symbol kekuatan prakertinya Sang Hyang Widhi dan bermanifestasi sebagai Sang Hyang Semara Ratih, dewa kecantikan serta kebijaksanaan symbol pengantin wanita. (2) Kelabang Kala Nareswari (Kala Badeg) simbol calon pengantin, yang diletakkan sebagai alas upakara makala-kalaan serta diduduki oleh kedua calon pengantin. (3) Tikeh Dadakan (tikar kecil),diduduki oleh pengantin wanita sebagai simbol selaput dara dari wanita. Kalau dipandang dari sudut spiritual, tikeh dadakan adalah sebagai symbol kekuatan Sang Hyang Prakerti (kekuatan Yoni). (4) Keris sebagai kekuatan Sang Hyang Purusa (kekuatan lingga) calon pengantin pria. Biasanya nyungklit keris, dipandang dari sisi spiritualnya sebagai lambang kepurusan dari pengantin pria. (5) Benang Pepegatan dalam mekala-kalaan dibuatkan benang putih pada kedua ujung benang masing-masing dikaitkan pada cabang pohon dapdap. Dengan upacara makala-kalaan sebel pengantin yang disebut sebel kendalan menjadi sirna dengan upacara penyucian. Dari segi spiritual benang ini sebagai symbol dari lapisan kehidupan dimana sang pengantin telah siap untuk menuju jenjang Grahasta Asrama. (6) Tegen-tegenan merupakan simbol dari pengambil alihan tanggung jawab sekala dan niskala. Perangkat tegentegenan : Batang tebu berarti pengantin bisa hidup bertahap. Cangkul sebagai simbol Ardha Candra, cangkul sebagai alat bekerja berkarma berdasarkan dharma. Periuk simbol windhu. Buah kelapa simbol Brahma (Sang Hyang Widhi). Seekor yuyu simbol memohon keturunan dan kerahayuan. Suwun-suwunan (sarana jinjingan) berupa bakul yang dijinjing mempelai wanita, yang berisi talas, kunir, beras, dan bumbu-bumbuan melambangkan tugas wanita atau istri mengembangkan benih yang diberikan suami. (7) Dagang-dagangan melambangkan kesepakatan dari suami istri untuk membangun rumah tangga dan siap menanggung segala resiko yang timbul. (8) Sapu Lidi simbol Tri Kaya Parisudha. Pengantin pria dan wanita saling mencemati satu sama lain, yang 
artinya saling memperingatkan agar selalu ingat dengan kewajiban melaksanakan Tri Rna, berdasarkan ucapan baik, prilaku yang baik, dan pikiran yang baik. (9) Sambuk Kupakan atau kala sepetan merupakan serabut kelapa yang dibelah tiga, di dalamnya diisi sebutir telor bebek, kemudian dicakup kembali di luarnya diikat dengan benang berwarna tiga (tri datu). Serabut kelapa dibelah tiga simbol dari Tri guna (satwam, rajas dan tamas). Benang tridatu simbol dari Tri Murti (Brahma, Wisnu dan Siwa) melambangkan kesucian. Telor bebek simbol manik. Mempelai saling tendang serabut kelapa sebanyak tiga kali, setelah itu secara simbolis diduduki oleh pengantin wanita. Jika mengalami perselisihan agar bisa saling mengalah, serta menyadari langsung kesalahannya. (10) Tetimpug yaitu bambu tiga batang yang di bakar dengan api dayuh yang bertujuan memohon penyupatan dari Sang Hyang Brahma. Setelah upacara makala-kalaan selesai dilanjutkan dengan cara membersihkan diri hal itu disebut dengan "angelus wimoha" yang berarti melaksanakan perubahan nyomia Bhuta Kala Nareswari agar menjadi Sang Hyang Semara Jaya dan Sang Hyang Semara Ratih agar harapan dari perkawinan ini bisa lahir anak yang suputra.

\section{Mewidhi Widana}

Upacara ini dipimpin oleh Sulinggih/Ida Peranda. Setelah sembahyang di depan bebanten, lalu kedua mempelai melakukan sembahyang di Sanggah keluarga laki-laki yang dipimpin oleh pemangku sanggah. Prosesi ini untuk menyampaikan kepada para leluhur, bahwa ada pendatang baru yang akan menjadi anggota keluarga dan akan melanjutkan keturunannya. Semua itu sebagai pertanda sahnya pernikahan pasangan pengantin di hadapan Ida Sang Hyang Widhi Wasa, adat, dan masyarakat.

\section{Mejauman}

Prosesi ini juga disebut upacara mepamit yang dilakukan di Sanggah pihak pengantin wanita. Makna dari upacara ini untuk berpamitan kepada para leluhur pihak mempelai wanita, karena sudah menikah dan menjadi tanggungjawab keluarga pengantin pria. Pada hari yang telah disetujui oleh kedua belah pihak maka keluarga pengantin serta kedua mempelai, datang ke keluarga wanita. Rombongan membawa banten antara lain alem, ketipat bantal, sumping, cerorot, apem, kuskus, wajik, kekupa, bermacam buah-buahan serta lauk pauk khas Bali.

\section{SIMPULAN DAN SARAN}

Berdasarkan kajian materi diatas dapat disimpulkan bahwa upacara pawiwahan adalah upacara yang sakral dimana seorang laki-laki dan perempuan mengikatkan diri secara lahir bathin sebagai suami istri untuk membangun rumah tangga yang harmonis melalui suatu upacara pembersihan secara sekala dan niskala. Tujuan dari pawiwahan adalah mendapatkan keturunan dan menebus dosa para orang tua dengan menurunkan seorang putra yang suputra sehingga akan tercipta keluarga yang bahagia di dunia (jagadhita) dan kebahagiaan kekal (moksa). Sistem Pawiwahan dalam kitab Manava Dharmasastra disebutkan ada delapan yaitu Daiwa Wiwaha, Arsa Wiwaha, Prajapati Wiwaha, Asura Wiwaha, Gandharva Wiwaha, Raksasa Wiwaha, dan Paisaca Wiwaha. Dan dalam adat Bali ada empat bentuk pawiwahan diantaranya: Sistem memadik/ meminang, sistem ngerorod/ngerangkat, sistem nyentana, dan sistem kejangkepan.

Rangkaian upacara pawiwahan yaitu (1) menentukan hari baik dimana keluarga yang akan melakukan upacara pawiwahan memilih hari baik sesuai dengan kalender Hindu Bali, (2) upacara ngekeb adalah untuk mempersiapkan calon pengantin wanita, (3) penjemputan mempelai wanita yaitu pihak keluarga mempelai pria menjemput calon dari mempelai wanita. (4) mungkah lawang yaitu utusan dari calon mempelai laki-laki datang untuk mengetok pintu kamar calon pengantin wanita, (5) upacara mesegeh agung bermakna sebagai ungkapan 
selamat datang kepada calon pengantian wanita, (6) upacara mabyakala yaitu upacara untuk membersihkan lahir batin terhadap kedua mempelai, (7) Mewidhi widana adalah untuk menyampaikan kepada para leluhur, bahwa ada satu pendatang baru yang akan menjadi anggota keluarga dan akan melanjutkan keturunannya, (8) mejauman disebut upacara mepamit/berpamitan atau perpisahan yang dilakukan di sanggah pihak pengantin wanita.

Dengan adanya artikel ini diharapkan umat Hindu membaca dan agar dapat memahami pengertian, tujuan serta mengetahui sistem dan rangkaian dari upacara pawiwahan dalam agama Hindu. Agar dalam pelaksanaannya tidak ada penyimpangan tatwa, etika dan ritual, walaupun tetap dibolehkan mengikuti desa, kala dan patra.

\section{DAFTAR PUSTAKA}

Agus, Kusuma Wijaya I Gede, 2017, makalah perkawinan menurut hindu, http://igedeaguskesumawijaya.blogspot.com/2017/06/makalah-perkawinanmenurut-hindu.html, diunduh pada 31 Mei 2020.

Arka, Dewa, 2010, Perkawinan Menurut Adat Bali, https://dewaarka.wordpress. com/2010/01/13/perkawinan-menurut-adat-bali, diunduh 31 Mei 2020.

Bem, S,L. 1981. Gender, Schema Theory: A cognitive Account of Sex Typing. Psychological Review 369-371.

Departemen Pendidikan dan Kebudayaan. 1997. Kamus Besar Bahasa Indonesia. Jakarta: Balai Pustaka.

Djajasudarma, Fatimah. 1999. Pemahaman Ilmu Makna. Bandung: PT Refika Aditama.

Fakih, Mansour. 2008. Analisis Gender dan Transformasi Sosial. Yogyakarta: INSISTPress

John. D. DeLamater \& Morgan Sill. 2005. Jurnal of Sexual Desire in Later Life. Jakarta: Kompas.

Koentjaraningrat. (1992). Kebudayaan Mentalitas dan Pembangunan. Jakarta: PT. Gramedia Pustaka Umum.

Mardalis. 2003. Metode Penelitian Suatu Pendekatan Proposal. Jakarta: Bumi Aksara.

Mashita, Dewi, 2017, Adat Istiadat Masyarakat Bali, https://books.google.co.id/ books?id=z6_dDwAAQBAJ\&printsec=frontcover $\#=$ =onepage \& $q \& f=f a l s e$, diunduh 16 Juni 2020.

Mosse, J. C. 2007. Gender \& Pembangunan. Yogyakarta: Pustaka Pelajar

Pangkahila, Wimpie. 2001. Seks yang Indah. Jakarta: Kompas.

Pateda, M. 2001. Semantik Leksikal. Jakarta: Rineka Cipta. 
Jurnal Widya Sastra Pendidikan Agama Hindu, Vol. 3, No. 22020

e-ISSN : 2656-7466, p-ISSN : 1907-9559

Pudja, G dan Sudharta, Rai,Tjok. 1977. Manawa Dharmasastra (Manu Dharma Sastra atau Weda Smrti Compendium Hukum Hindu. Jakarta: C.V Junasco.

Titib I Made. 2006. Menumbuhkembangkan Pendidikan Agama Pada Keluarga. Denpasar: Bali Post.

Ullman, Stephen. 1972. Semanties An Introduction to the Science of Meaning. Oxford: Basil Blackwell.

Sri Weda Gangga DWS IGA. 2008. Eksistensi Perkawinan Adat Ngerorod Di Bali Dalam Hal Tidak Terpenuhinya Syarat Tertentu Menurut Hukum Perkawinan Nasional $\quad \mathrm{Di}$ Indonesia,https://adoc.tips/eksistensi-perkawinan-adatngerorod-di-bali-dalam-hal-tidak.html, diunduh pada 16 Juni 2020.

Sugiyono. 2009. Metode Penelitian Kuantitatif, Kualitatif dan R\&D. Bandung: Alfabeta. 